\title{
One Dimensional Site Response Analysis of Liquefaction Potential along Coastal Area of Bengkulu City, Indonesia
}

\author{
Mase, L.Z. ${ }^{1}$
}

\begin{abstract}
This paper presents one dimensional non-linear site response analysis of liquefaction potential caused by the 2000 and the 2007 earthquakes in coastal area of Bengkulu City, Bengkulu, Indonesia. Site investigations, including Standard Penetration Test (SPT) and shear wave velocity $\left(\mathrm{V}_{\mathrm{S}}\right)$ measurement, were conducted in three locations along the coastal area of Bengkulu City. Further, the site investigation data were used in simulation of one-dimensional non-linear site response analysis by applying the synthetic ground motions at bedrock. The results show that liquefaction could happen at 0 to $1.5 \mathrm{~m}$ deep. This was indicated by the excess pore water pressure ratio $\left(r_{u}\right)$ which exceeded one. At depth between $1.5 \mathrm{~m}$ and $20 \mathrm{~m}$, the excess pore water pressure almost reached the initial effective stress decreasing the effective confinement pressure close to zero. The results also indicated that liquefaction is possible to occur in this depth range if a stronger earthquake occurs.
\end{abstract}

Keywords: Liquefaction; non-linear analysis; coastal area; excess pore water pressure.

\section{Introduction}

During the last decade, two strong earthquakes occurred in Bengkulu City, Indonesia, i.e. the $8 \mathrm{M}_{\mathrm{w}}$ Earthquake in 2000 and the $8.7 \mathrm{M}_{\mathrm{w}}$ Earthquake in 2007. Both earthquakes not only resulted in the devastating impact to many buildings but also resulted in some liquefaction, which were found along coastal area of Bengkulu City.

Several liquefaction studies using empirical analysis in coastal area of Bengkulu City had been conducted. Muktadir [1] studied liquefaction potential in Lempuing, a part of coastal area of Bengkulu City. In the study, the seismic design code of Indonesia (SNI 031726-2012 [2] was considered in analysis. The result of the study was furthermore interpreted by Misliniyati et al. [3] in a vulnerable map of liquefaction corresponding to the impacted depth. Extending the previous study, Monalisa [4] analysed the liquefaction potential in the same area using the simple probability concept. Furthermore, Mase and Sari [5] extended the study of Monalisa [4] to compose the liquefaction resistance curve based on peak ground acceleration and grain size distribution. In 2016, Mase and Somantri [6,7] studied the other important coastal areas in Bengkulu City, i.e. Pantai Panjang and Anggut, which are known as the tourists destinations in Bengkulu City.

\section{${ }^{1}$ Department of Civil Engineering, Faculty of Engineering, Uni- versity of Bengkulu, Bengkulu, INDONESIA \\ Email: lmase@unib.ac.id}

Note: Discussion is expected before November, $1^{\text {st }} 2018$, and will be published in the "Civil Engineering Dimension", volume 21, number 1, March 2019.

Received 01 December 2016; revised 20 August 2018; accepted 21 August 2018.
In this recent study, Mase and Somantri [6,7] considered the shear wave velocity $\left(\mathrm{V}_{\mathrm{S}}\right)$ data to investigate liquefaction potential. Mase [8] conducted the liquefaction potential analysis along coastal area of Bengkulu City using several SPT methods. Mase [8] also suggested that Idriss and Boulanger's method as the suitable method for Bengkulu City. The method is consistent with liquefaction evidence found during the $8 \mathrm{Mw}$ Earthquake in 2000. Mase [9] performed a simulation of liquefaction potential using finite element analysis along coastal area of Bengkulu Province. In the study, Mase [9] concluded that along coastal area of Bengkulu City was probably liquefied during the $8.7 \mathrm{M}_{\mathrm{w}}$ earthquake in 2007. In general, the previously mentioned studies concluded that the coastal area of Bengkulu City was very vulnerable to liquefaction.

Liquefaction triggered by earthquakes also occurred in some areas in Indonesia, such as Padang in 2009, Yogyakarta in 2006, and Aceh in 2004. Those areas were also studied by many Indonesian researchers. Hakam [10] studied liquefaction potential of local sandy soils due to Padang earthquake in 2009. The study showed that Padang sandy soils were vulnerable to liquefaction, especially based on grain size criteria and cyclic stress ratio. Liquefaction during Yogyakarta earthquake was studied by Yogatama and Fathani [11]. Based on their study, the Southern and Eastern parts of Yogyakarta were identified as high to very high-risk area to liquefaction. Tohari et al. [12] studied the liquefaction potential in Aceh that in 2004 also experienced many liquefaction phenomena. The study confirmed that liquefaction could occur as reported by Tohari et al. [13] and Tobita et al. [14]. In general, both studies stated that liquefaction could occur at shallow depth during Aceh earthquake in 2004. 
In general, the previously mentioned liquefaction studies in Indonesia are still focused on preliminary investigation based on site investigation data, such as Cone Penetration Test (CPT) and Standard Penetration Test (SPT). However, the detail study of site response analysis of liquefiable soils is still rarely performed. The objective of this study is to present non-linear site response analysis to the liquefaction potential during the 2007 and 2000 earthquakes in Bengkulu City. The excess pore water pressure ratio $\left(r_{u}\right)$ and the predicted horizontal displacement corresponding to depth are analysed in this study. In addition, the percentage of impacted depth is analysed. To understand the effect of cyclic loading to sand layers, soil behaviour interpretation during loading is also presented.

\section{Study Area and Geological Condition}

This study is focused on three locations along coastal area of Bengkulu City (Figure 1). They are noted as BH-1 (Anggut), BH-2 (Pantai Panjang), and BH-3 (Lempuing). Anggut and Pantai Panjang are the tourism zones where many souvenir markets and hotels exist. In addition, the social-economy aspect is also concentrated there. Different from two previous locations, Lempuing is an urban area, where local government offices and housings exist.

In the study area, site investigations including SPT and $V_{S}$ tests were conducted. The results of site investigation are presented in Figure 2. In general, sub-soils in the study area are dominated by sandy soils. Loose sand classified as SP (poorly graded sand) is found at the depth of 0 to $1.5 \mathrm{~m}$, and 7.5-9 m. This soil type has $\left(\mathrm{N}_{1}\right)_{60}$ of 5-6 blows/ft and FC (fines content) of $4-7 \%$. Silty sand (SM) exists at depth range of 1.5 to $22.5 \mathrm{~m}$, with $\left(\mathrm{N}_{1}\right)_{60}$ of $15-25$ blows $/ \mathrm{ft}$ and $\mathrm{FC}$ of 10 to $18 \%$. At depth range of 22.5 to $30 \mathrm{~m}$, Clayey sand (SC) and silty sand (SM) are found. $\left(\mathrm{N}_{1}\right)_{60}$ of these layers ranged in 25-35 blows/ft, with FC of 16-22\%. According to NEHRP (National Earthquake Hazard Reduction Program) [16], site class of the study area was classified as stiff soil (site class D), with $\mathrm{V}_{\mathrm{S} 30}$ (time-averaged $\mathrm{V}_{\mathrm{S}}$ up to $30 \mathrm{~m}$ deep) of 298 to $302 \mathrm{~m} / \mathrm{s}$. The ground water table in these locations are found about 0 to $2 \mathrm{~m}$ deep.

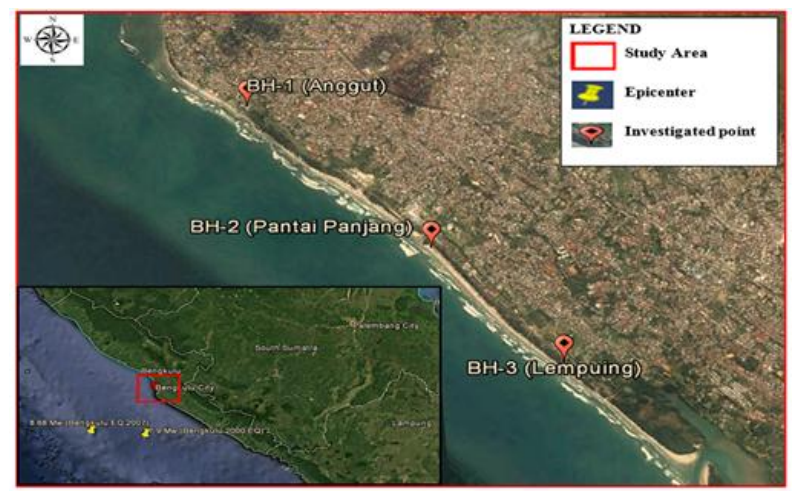

Figure 1. Study Area (modified from Google Earth [15]).

\section{Methodology}

\section{Constitutive Modelling}

The cyclic stress-strain behaviour in saturated sandy soil is complex [17]. However, there are exceptions for loose sands at low confining pressure. Loose sand at low confining pressure normally behave as a contractive material that is very sensitive to undergo the dynamic load. This soil type is also very sensitive

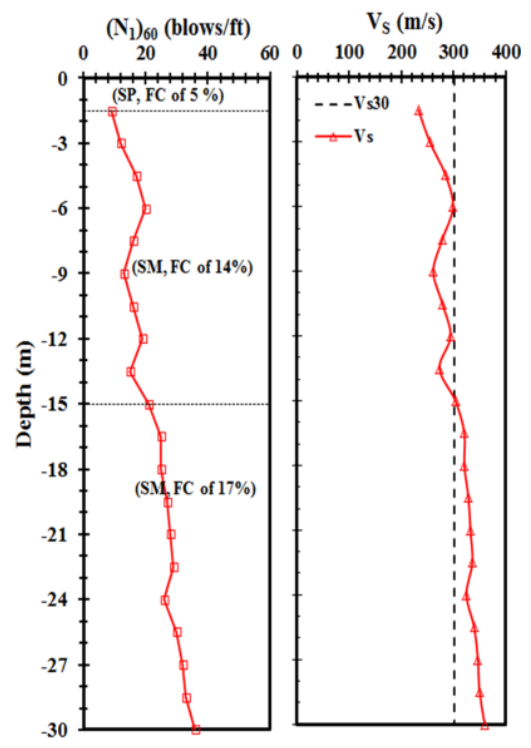

(a) $\mathrm{BH}-1$

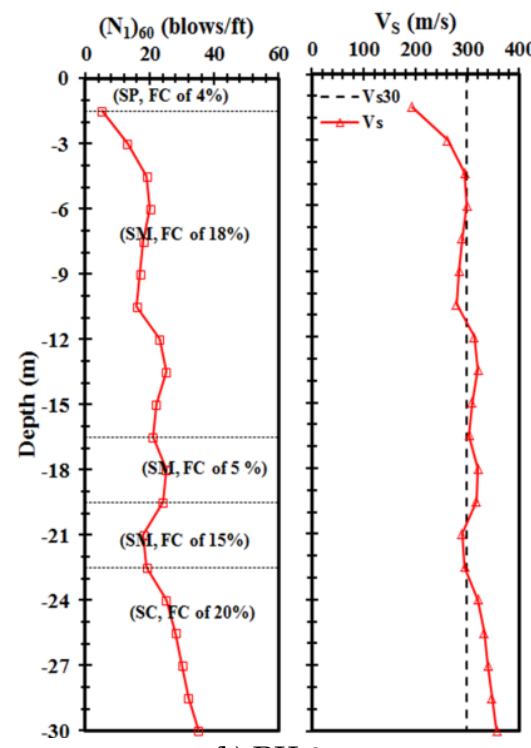

(b) $\mathrm{BH}-2$

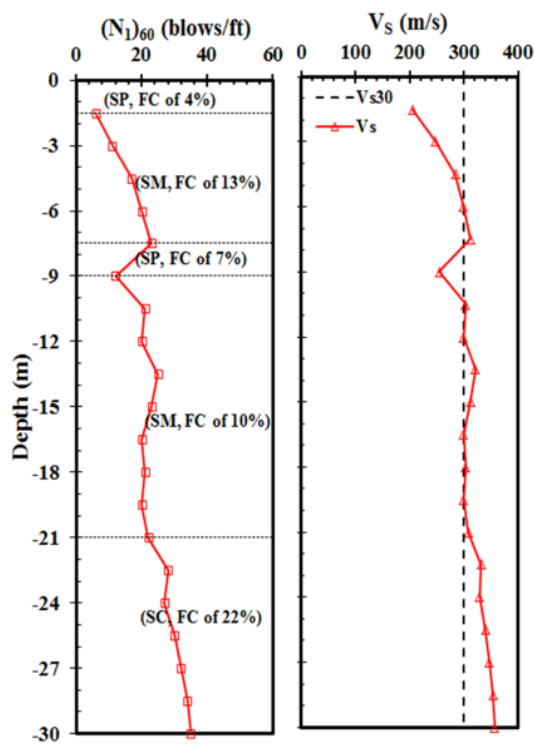

(c) $\mathrm{BH}-3$

Figure 2. SPT and Vs Data 
to undergo the excess pore pressure due to the earthquake shaking. Ishihara et al. [18] introduced that a phase transformation of sand appeared due to cyclic loading in effective stress form as presented in Figure 3. In Figure 3, $p^{\prime}$ is mean vertical effective stress, $\tau$ is shear stress, $\gamma$ is shear strain, $\gamma_{d}$ is shear strain difference between failure and transformation conditions and $\mathrm{PT}$ is the phase transformation surface. The cyclic loading moves the effective stress to the left, indicating there is an increase of pore water pressure. The behaviour of sand transforms from contractive to dilative, when a certain cyclic stress ratio is reached. It happens when the effective stress path reaches the phase transformation line (PT line). At this stage, there is a reduction of excess pore water pressure. Therefore, there is an accumulation of excess pore water pressure and is followed by the reduction of excess pore water pressure. Based on the illustration, it can be concluded that the phenomenon in sandy soils is complex and inelastic as well as non-linear; therefore, there is a necessity to use a sophisticated soil modelling.

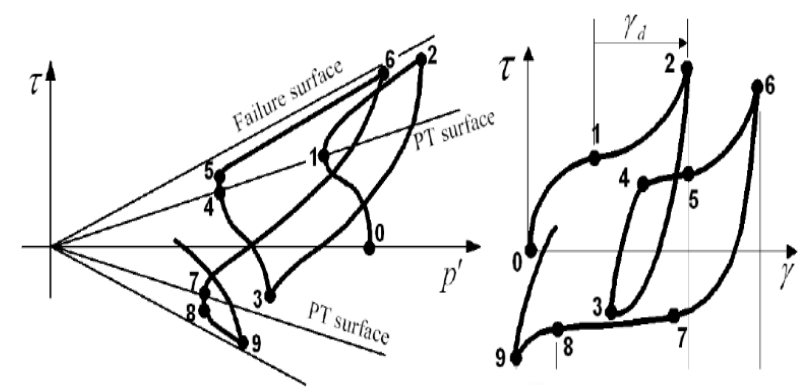

Figure 3. Effective Stress Path-shear Strain-shear Stress of Sand Under Dynamic Load [22]

The complex cyclic mobility illustrated in Figure 3 inspired the idea of soil liquefaction to consider the magnitude of shear strain in soil. Parra [19] and Yang [22] implemented the phase transformation to develop constitutive modelling of soil liquefaction based on the multi-yield surface plasticity of Prevost [21]. Furthermore, Elgamal et al. [22] developed a model focusing on magnitude of cycle by cycle, permanent shear strain accumulation in several sand types. The complex phase including contractive, perfectly plastic, and dilative phases associated with flow rule, is able to change the characteristic model response for producing the salient cyclic mobility mechanism. In addition, the model is able to exercise more direct control over shear strain accumulation. As this method follows the multi-yield surface and is combined with very complex phase, a new kinematic hardening model was developed (Figure 4). On each incremental step, the new kinematic hardening model evaluates the stiffness in calculation of finite element; the excess pore water pressure under cyclic loading can also be computed, either if the permeability coefficient is large or if the loading frequency is relatively small.

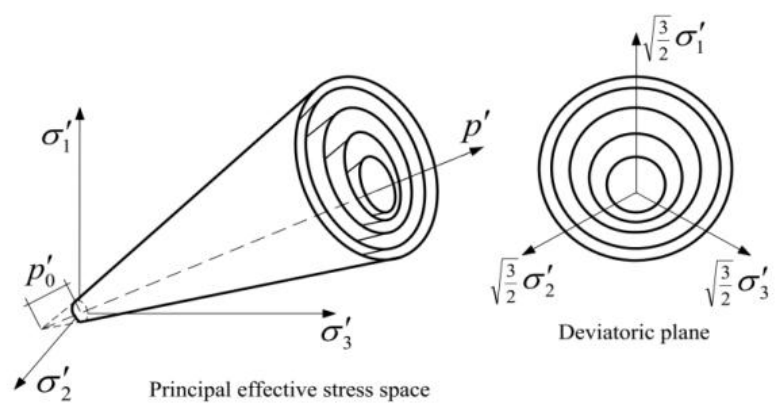

Figure 4. Multi-yield Surface in Principal Stress Space and Deviatoric Plane (after Prevost [22], Parra [19], and Yang [20]).

\section{Computational Analysis and Modelling Criteria}

In the current study, one-dimensional non-linear liquefaction potential analysis is performed. This method was proposed by Elgamal et al. [22]. The model is capable of simulating the non-linearity by using the incremental plasticity to model permanent deformation and hysteretic damping. Finite element using the coupled solid-fluid approach is used in both dry and saturated strata and able to generate and dissipate pore water pressure. In the computation process, this method can explore the information of seismic response analysis and soil behaviour under dynamic load, such as earthquake.

In the analysis, the soil column is assumed to be fully saturated that reflects the normal condition of potentially liquefied soil. The initial effective stress of soil $\left(\sigma_{v}\right)$ is estimated based on the soil density $(\gamma)$ and depth of ground water table. The lateral effective stress $\left(\sigma_{h}\right)$ is estimated based on the effective stress and the coefficient of lateral earth pressure at rest $\left(K_{0}\right)$. Excess pore water pressure ratio $\left(r_{u}\right)$ is calculated from the comparison of effective stress and excess pore water pressure $(\Delta u)$. Mase et al. [23] illustrated the modelling of one-dimensional seismic response analysis in liquefiable layer, as shown in Figure 5. There is no drainage path on lateral direction. The soil layers are underlain by the impermeable bedrock surface. The boundary condition is limited on vertical direction of soil column and both displacements on vertical and horizontal direction can be calculated during seismic wave propagation. Mesh size of soil layers are assumed as $0.5 \mathrm{~m}$. This value is obtained from wave length analysis as applied by Mase et al. [23]. Moreover, Pender et al. [17] also suggested that mesh of $0.5 \mathrm{~m}$ is suitable for one dimensional analysis of seismic response analysis.

During seismic wave propagation, excess pore water pressure would be generated on vertical direction. The excess pore water pressure is then compared with the initial effective stress to determine excess 
pore water pressure ratio $\left(r_{u}\right)$. The estimation of sediment thickness of study area was considered based on the study of Refrizon et al. [24], i.e. about $50 \mathrm{~m}$ deep. As the information of soil profile in this study is only $30 \mathrm{~m}$; therefore, for the remaining depths (30 to $50 \mathrm{~m}$ ), the soil profile is linearly assumed by interpolating $\mathrm{V}_{\mathrm{S}}$ value at $50 \mathrm{~m}$ equal to $760 \mathrm{~m} / \mathrm{s}$ [25]. The interpolating result of adjusted $\mathrm{V}_{\mathrm{s}}$ is presented in Figure 6.

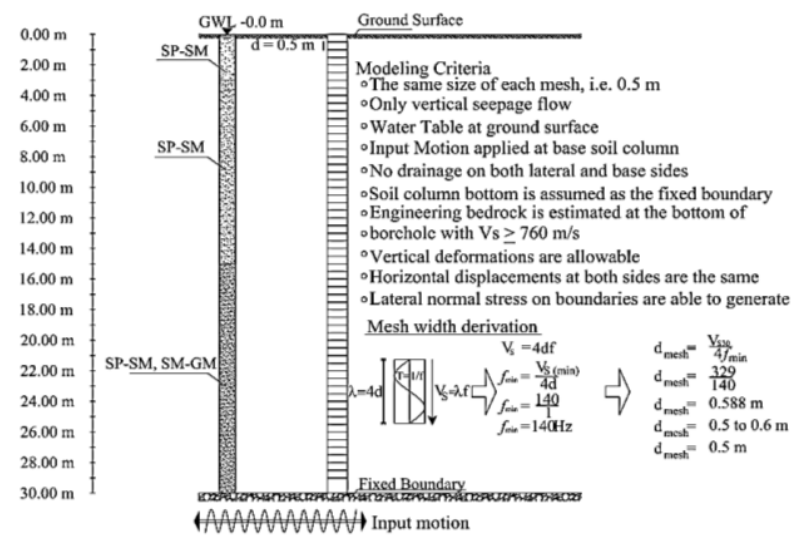

Figure 5. Illustration of One-dimensional Seismic Analysis [23].

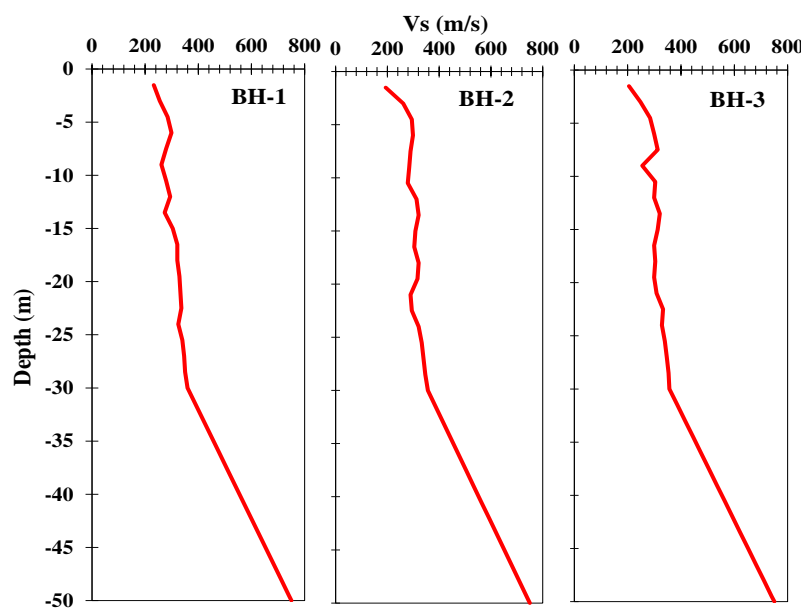

Figure 6. Bedrock Interpolation based on Vs

The material properties of each layer are determined based on either undisturbed or disturbed sampling tests of the soil sample taken from boring test. These parameters are used as the input material for the soil properties. In this study, an open-source program called Cyclic1D is employed in the analysis. The brief explanations of material properties are presented below:

- $\quad \gamma$ is density of soil, FC is fines content of soil, $\mathrm{c}$ is cohesion of soil, $\phi$ is internal friction angle of soil, and $\mathrm{k}$ is permeability coefficient of soil;

- $V_{\text {Saverage }}$ is average shear wave velocity of soil layer;

- $\mathrm{K}_{0}$ is coefficient of lateral earth pressure at rest;

- $\quad p_{\text {reff }}^{\prime}$ and $y_{\max }$ are reference mean effective confinement and peak shear strain, respectively;
- Liq is liquefaction parameters, which dictates the extent of shear strain accumulation (e.g. phases 4-5 and 7-8 (Figure 3)). Recommended range of values is $0.025-0.00$ (for very loose to very dense sands);

- $c_{1}$ and $c_{2}$ are the contraction parameters. $c_{1}$ dictates the rate of pore pressure build up under undrained condition. Recommended range of values is 0.3 to 0.0 (for very loose to very dense sands). $c_{2}$ reflects the effect of overburden pressure on the contraction behaviour. Recommended range of values is 0.2 to 0.6 (for very loose to very dense sands);

- $\quad d_{1}$ and $d_{2}$ are the dilation parameters. $d_{1}$ reflects the rate of volume expansion or reduction of pore pressure. Recommended range of values is 0.0 to 0.6 (very loose to very dense sands). $d_{2}$ dictates the effect of accumulated shear strain on dilation parameter. Recommended value is 10 .

\section{Groundmotion}

Since the real ground motions of the 2000 and 2007 earthquakes are not available, then the synthetic ground motions are generated by using SeismoArtif Program from Seismosoft [26]. The main parameters to generate the ground motions using this program include maximum PGA, focal depth, distance to rupture $\left(R_{\mathrm{jb}}\right)$, moment magnitude $\left(\mathrm{M}_{\mathrm{w}}\right)$, earthquake source mechanism, and targeted spectral acceleration corresponding to local site condition. The maximum accelerations of both earthquakes were $0.244 \mathrm{~g}$ and $0.223 \mathrm{~g}$ for the 2000 and the 2007 earthquake, respectively. The 2000 and 2007 earthquake had magnitude of 8 and $8.7 \mathrm{M}_{\mathrm{w}}$, respectively, and were triggered by subduction zone activity in the Western Sumatera Island. The focal depths of both earthquakes were $33 \mathrm{~km}$ for the 2000 earthquake and 30 $\mathrm{km}$ for the 2007 earthquake, respectively. The $R_{\mathrm{jb}}$ of the 2000 Earthquake was $116 \mathrm{~km}$ and the 2007 Earthquake, $122 \mathrm{~km}$ to Bengkulu City. In general, the requirement related to ground motion released by Indonesian Seismic Design Code [27], is considered in seismic ground response analysis. This regulation requires at least 5 ground motions that should be considered in seismic wave propagation analysis in Indonesia. However, since this study is addressed to observe the soil behaviour during earthquake, the synthetic ground motions of each 2007 and the 2007 earthquake are reasonably generated and used.

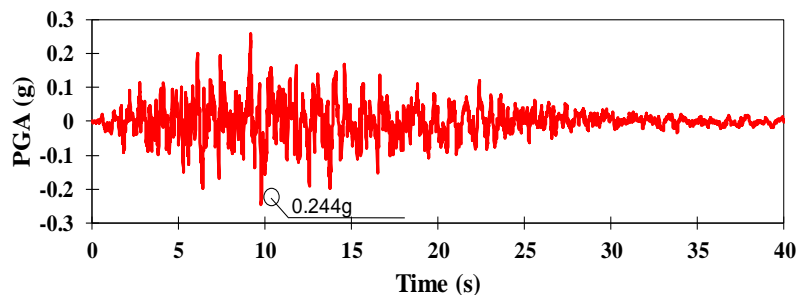

Figure 7. Synthetic Ground Motion of the 2000 Earthquake 


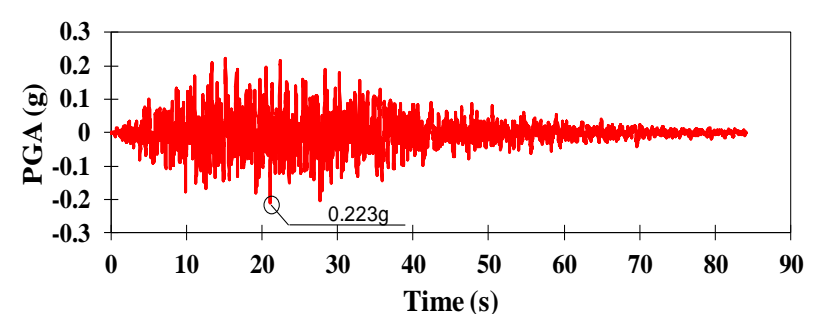

Figure 8. Synthetic Ground Motions of the 2007 Earthquake

\section{Result and Discussion}

\section{Excess Pore Water Pressure Ratio}

Figure 9 present the interpretation of $r_{u}$ profile due to 2000 and 2007 earthquakes respectively. In general, both earthquakes are able to trigger liquefaction on all sites along coastal area of Bengkulu City. The results also agree with liquefaction evidences found during the 2000 earthquake (reported by Arya [28]) and the 2007 earthquake (reported by EERI [29]). From 0 to 1.5 $\mathrm{m}$, sand layers at each borehole undergo liquefaction. The excess pore water pressure has reached and exceeded the initial effective stress. This depth is dominated by loose sand having $\left(\mathrm{N}_{1}\right)_{60}$ of 5-6 blows/ft. From 1.5 to $15 \mathrm{~m}, r_{u}$ is less than one but more than 0.9 , so liquefaction does not happen. However, soil layer may be in critical condition (liquefaction almost happens), because $r_{u}$ is very close to 1 . This depth is dominated by SM, with $\left(\mathrm{N}_{1}\right)_{60}$ of $15-25$ blows/ft. At depth of 15 to $30 \mathrm{~m}$, generated $r_{u}$ is 0.3 to 0.8 . At this depth range, the soil layer is generally safe. $\left(\mathrm{N}_{1}\right)_{60}$ of this depth range is $23-35$ blows/ft.

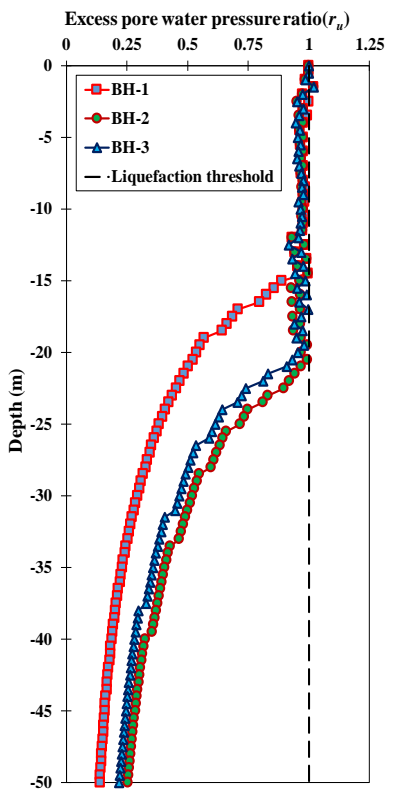

(a)

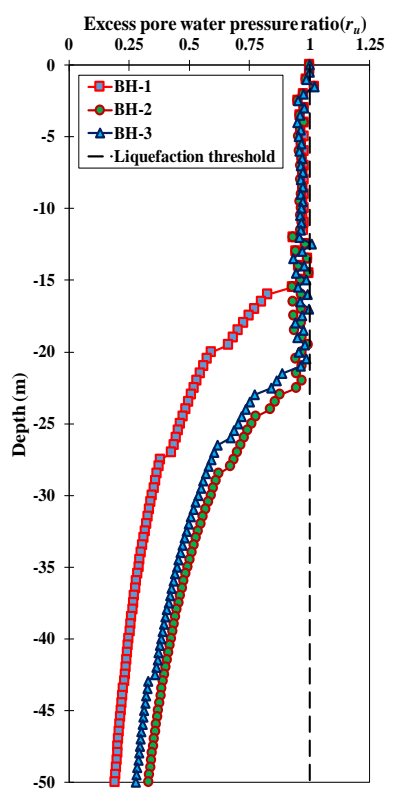

(b)
Figure 9. $r_{u}$ vs Depth for (a) The 2000 Earthquake, (b) The 2007 Earthquake

\section{Percentage of Total $r_{u}$ Maximum and Impacted Depth}

Table 1 presents the percentage of $r_{u}$ maximum for total of $30 \mathrm{~m}$ deep. In Table $1, r_{u}$ maximum is divided into 7 criteria. In general, $\mathrm{BH}-2$ (Pantai Panjang) experiences the worst impact. It can be seen from the distribution of $r_{u}$ maximum. In $\mathrm{BH}-2$ the distribution of $r_{u}$ maximum in range of $0.9<r_{u}<1$ is the largest. It indicates that $\mathrm{BH}-2$ is in more critical condition than the other investigated points $\mathrm{BH}-1$ (Anggut) and $\mathrm{BH}$ 3 (Lempuing). Between the 2000 and the 2007 Earthquakes, the 2007 earthquake has resulted in more serious liquefaction impact than the 2000 earthquake. It is reflected by the distribution of $r_{u}$ maximum in range of $0.9<r_{u}<1$, which is not significantly different to each other.

Furthermore, the interpretation of the impacted depth is shown in Table 2. In Table 2, BH-2 also undergoes more serious impacted depth than other investigated points, if the larger earthquake occurs. It can be seen from the distribution of $r_{u}$ maximum in range of $0.9<r_{u}<1$ (i.e. about $21 \mathrm{~m}$ deep). Similar to the interpretation in Table 1 , it can be concluded that the 2007 earthquake results in almost similar impact as 2000 earthquake.

\section{Horizontal displacement}

Figures 10(a) and (b) present the interpretation of horizontal displacement due to the 2000 and 2007 earthquakes, respectively. In general, the horizontal displacement is identified on loose and silty sand layers of all investigated points, which have $\left(\mathrm{N}_{1}\right)_{60}$ of 5-6 blows/ft and $\left(\mathrm{N}_{1}\right)_{60}$ of 15-25 blows/ft, respectively. Those sand layers seem to easily degrade due to liquefaction and undergo lateral spreading at the ground surface. Due to liquefaction during both earthquakes, the horizontal displacement is about 0.2 to $0.5 \mathrm{~m}$, which occurs at depth of 0 to $20 \mathrm{~m}$. Both the 2000 and 2007 Earthquakes can potentially trigger the larger horizontal displacement at ground surface. The larger magnitude may cause more serious damage and trigger a higher liquefaction impact. At depth of 20 to $30 \mathrm{~m}$, horizontal displacement is very small. The existence of higher $\left(\mathrm{N}_{1}\right)_{60}$ (about 23-35 blows/ft) and higher effective confining pressure provided the high soil resistance against horizontal displacement due to liquefaction.

\section{Soil Behaviour under the 2000 and 2007 Earth- quakes}

\section{$B H-1$}

Figure 11 shows the soil behaviour interpretation of $\mathrm{BH}-1$. At depth of $0.5 \mathrm{~m}$ (Figure 11a), the repre- 
Table 1. Percentage of Total $r_{u}$ Maximum for $30 \mathrm{~m}$ Deep

\begin{tabular}{|c|c|c|c|c|c|c|c|}
\hline \multicolumn{4}{|c|}{ The 2000 Earthquake } & \multicolumn{3}{|c|}{ The 2007 Earthquake } \\
\hline \multirow{2}{*}{$r_{u}$ criteria } & \multicolumn{2}{|c|}{ Percentage of $r_{u}$ in overall sand layer } & \multirow{2}{*}{$r_{u}$ criteria } & \multicolumn{2}{c|}{ Percentage of $r_{u}$ in overall sand layer } \\
\cline { 2 - 4 } \cline { 6 - 8 } & $\mathrm{BH}-1$ & $\mathrm{BH}-2$ & $\mathrm{BH}-3$ & & $\mathrm{BH}-1$ & $\mathrm{BH}-2$ & $\mathrm{BH}-3$ \\
\hline$r_{u} \geq 1$ & 4.92 & 4.92 & 4.92 & $r_{u} \geq 1$ & 4.92 & 4.92 & 6.56 \\
\hline $0.9<r_{u}<1$ & 44.26 & 68.85 & 65.57 & $0.9<r_{u}<1$ & 47.54 & 70.49 & 63.93 \\
\hline $0.8<r_{u}<0.9$ & 4.92 & 4.92 & 3.28 & $0.8<r_{u}<0.9$ & 1.64 & 4.92 & 4.92 \\
\hline $0.7<r_{u}<0.8$ & 3.28 & 4.92 & 4.92 & $0.7<r_{u}<0.8$ & 8.20 & 9.84 & 8.20 \\
\hline $0.6<r_{u}<0.7$ & 4.92 & 8.20 & 6.56 & $0.6<r_{u}<0.7$ & 3.28 & 8.20 & 6.56 \\
\hline $0.5<r_{u}<0.6$ & 8.20 & 8.20 & 8.20 & $0.5<r_{u}<0.6$ & 11.48 & 1.64 & 9.84 \\
\hline$r_{u}<0.5$ & 29.51 & 0.00 & 6.56 & $r_{u}<0.5$ & 22.95 & 0.00 & 0.00 \\
\hline
\end{tabular}

Table 2. Percentage of Impacted Depth for $30 \mathrm{~m}$ Deep

\begin{tabular}{|c|c|c|c|c|c|c|c|}
\hline \multicolumn{4}{|c|}{ The 2000 Earthquake } & \multicolumn{4}{c|}{ The 2007 Earthquake } \\
\hline \multirow{2}{*}{$r_{u}$ criteria } & \multicolumn{2}{|c|}{ Percentage of impacted depth in overall sand layer } & \multirow{2}{*}{$r_{u}$ criteria } & \multicolumn{2}{c|}{ Percentage of impacted depth in overall sand layer } \\
\cline { 2 - 3 } \cline { 6 - 8 } & BH-1 & BH-2 & BH-3 & & BH-1 & BH-2 & BH-3 \\
\hline$r_{u} \geq 1$ & 1.48 & 1.48 & 1.48 & $r_{u} \geq 1$ & 1.48 & 1.48 & 1.97 \\
\hline $0.9<r_{u}<1$ & 13.28 & 20.66 & 19.67 & $0.9<r_{u}<1$ & 14.26 & 21.15 & 19.18 \\
\hline $0.8<r_{u}<0.9$ & 1.48 & 1.48 & 0.98 & $0.8<r_{u}<0.9$ & 0.49 & 1.48 & 1.48 \\
\hline $0.7<r_{u}<0.8$ & 0.98 & 1.48 & 1.48 & $0.7<r_{u}<0.8$ & 2.46 & 2.95 & 2.46 \\
\hline $0.6<r_{u}<0.7$ & 1.48 & 2.46 & 1.97 & $0.6<r_{u}<0.7$ & 0.98 & 2.46 & 1.97 \\
\hline $0.5<r_{u}<0.6$ & 2.46 & 2.46 & 2.46 & $0.5<r_{u}<0.6$ & 3.44 & 0.49 & 2.95 \\
\hline$r_{u}<0.5$ & 8.85 & 0.00 & 1.97 & $r_{u}<0.5$ & 6.89 & 0.00 & 0.00 \\
\hline
\end{tabular}

sented point of SP layer, the excess pore water pressure has exceeded the initial effective stress and it indicates liquefaction. The ground motion also resulted in non-linear behaviour on shear stressshear strain. During earthquake, the effective confinement and shear stress decrease to zero. It shows that the soil has lost the soil resistance and undergoes liquefaction. In silty sand (SM) layer represented by depth of $9 \mathrm{~m}$ (Figure 11b), the excess pore water pressure is not large enough to trigger liquefaction, because it does not pass the initial effective stress. However, the excess pore water pressure may trigger the critical condition, which is shown by very close value to the initial effective stress. At this depth, the effective confinement pressure and shear stress almost reach zero. In the second silty sand (SM) layer at $22 \mathrm{~m}$ (Figure 11c), the excess pore water pressure is too small to trigger liquefaction. In addition, the excess pore water pressure due to seismic wave propagation is not strong enough to decrease effective confinement pressure at this depth.

The interpretation of soil behaviour of $\mathrm{BH}-1$ during the synthetic motion of 2007 earthquake is presented in Figure 12. In general, liquefaction occurs in SP Layer at shallow depth (Figure 12a). It is seen from the excess pore water pressure exceeding the initial effective stress. The excess pore water pressure also decreases the effective confinement pressure to zero, which means the soil has lost the shear resistance. In SM Layer, at depth of $9 \mathrm{~m}$ (Figure 12b), the soil layer seems to undergo critical condition, in which the excess pore pressure is very close to initial effective stress, but still has not triggered liquefaction yet. At this depth, the effective confinement pressure also almost decreases to zero. At depth of 22 $\mathrm{m}$ (Figure 12c) dominated by SM layer, liquefaction does not occur. It can be seen from the excess pore water pressure not exceeding the initial effective stress. The excess pore water pressure is also not large enough to reduce the effective confinement pressure to zero.

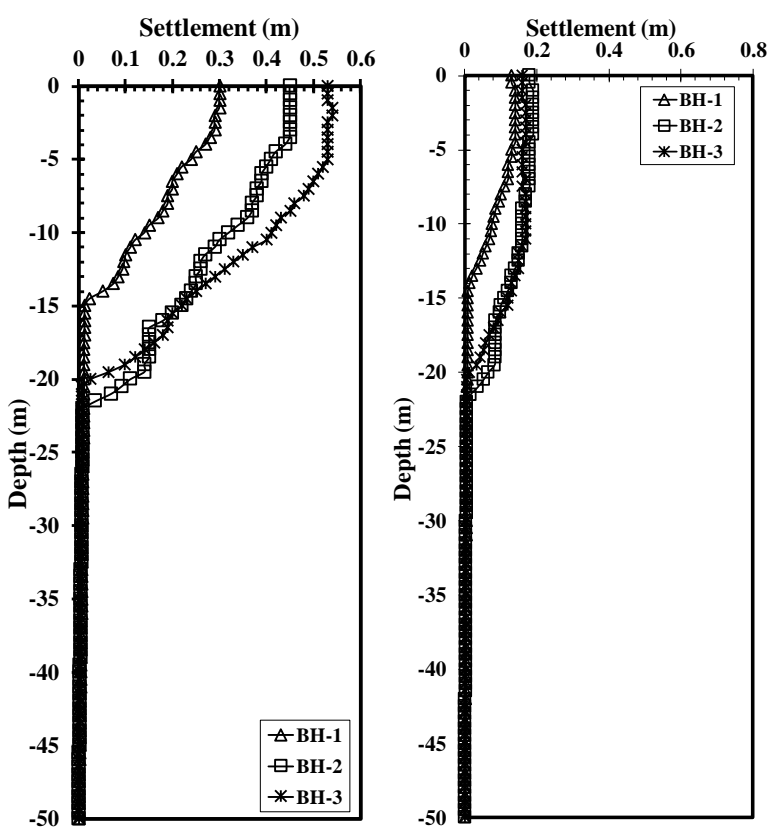

Figure 10. Horizontal Displacement vs Depth during (a) The 2000 Earthquake, (b) The 2007 Earthquake 
BH-2

Figure 13 presents soil behaviour of BH-2 under input motion of the 2000 earthquake. In general, in Figure 13a, at depth of $0.5 \mathrm{~m}$ (SP layer), liquefaction occurs. At this depth, the effective confinement pressure also decreases to zero. In Figure 13b, at depth of $9 \mathrm{~m}$ (SM layer), liquefaction does not occur, but excess pore water pressure almost reaches the initial effective stress. It seems to indicate that layer undergoes the critical condition. In addition, the effective confinement pressure also almost decreases to zero. This phenomenon is also observed at depth of $18.5 \mathrm{~m}$ (SM layer) in Figure 13c and $21.5 \mathrm{~m}$ (SM layer) in Figure 13d. In Figure 13e, for depth of 26.5 $\mathrm{m}$ (SC layer), the excess pore water pressure doesn't trigger liquefaction. The excess pore water pressure is not large enough to decrease effective stress at this point.

Figure 15 shows the interpretation of soil behaviour at BH-2 during the 2007 earthquake. Similar to BH1, BH-2 also undergoes liquefaction at shallow depth, as shown in Figure 14a (SP layer). the excess pore water pressure has exceeded the initial effective stress. It indicates that $r_{u}$ is more than one. The excess pore water pressure also decreases the effective confinement pressure to zero and results in the shear stress to be zero. The critical condition is also observed in SM layers, which are represented by depth of $9 \mathrm{~m}$ (Figure 14b), $18.5 \mathrm{~m}$ (Figure 14c), and $21.5 \mathrm{~m}$ (Figure 14d). At those points, the initial effective stresses are almost passed by the excess pore water pressure. During earthquake, the effective confinement pressure also undergoes the reduction and it almost reaches zero. In SC layer, at depth of $26.5 \mathrm{~m}$ (Figure 14e), the excess pore water pressure ratio is not large enough to trigger liquefaction.

\section{$B H-3$}

Figure 15 presents soil behaviour of $\mathrm{BH}-3$ under the 2000 earthquake. Similar to other sites, liquefaction also occurs at SP layer (Figure 15a). At this point the excess pore water pressure has passed the initial effective stress. The critical condition is also observed at depth of $4.5 \mathrm{~m}$ (SM layer) in Figure 15b, depth of $8.5 \mathrm{~m}$ in SP layer in Figure 15c, and depth of $15 \mathrm{~m}$ (SM layer) in Figure 15d. In Figure 15e, at depth of $25.5 \mathrm{~m}$ (SC layer), excess pore water pressure is not large enough to exceed the initial effective pressure. Therefore, liquefaction does not occur.
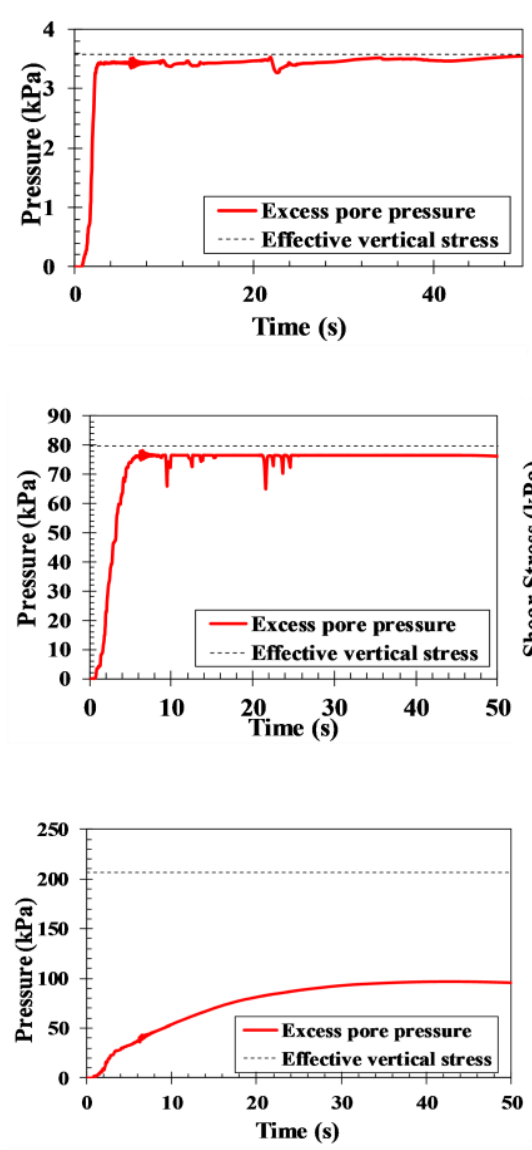

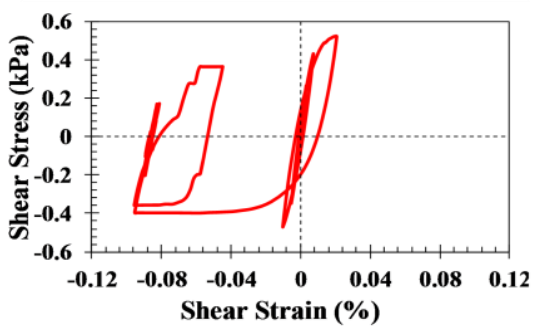

(a) Layer 1(at depth of $0.5 \mathrm{~m}$ )

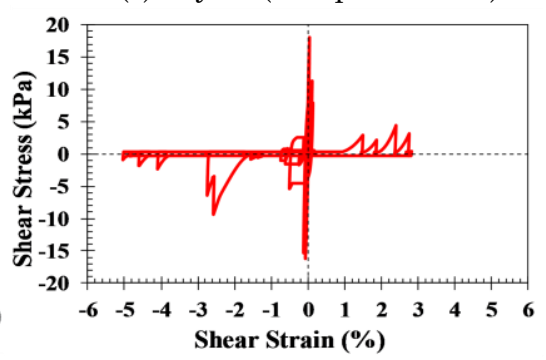

(b) Layer 2 (at depth of $9 \mathrm{~m}$ )

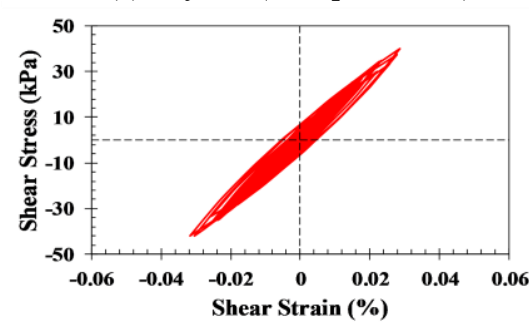

(c) Layer 3 (at depth of $22 \mathrm{~m}$ )
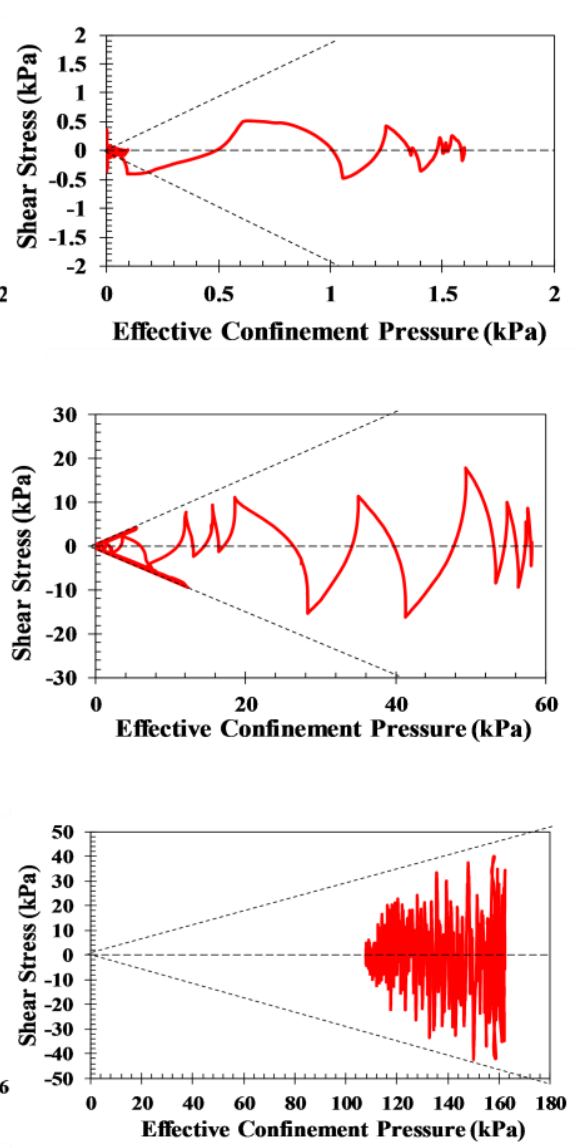

2000 Earthquake 
The interpretation of soil behaviour at $\mathrm{BH}-3$ during the 2007 earthquake is presented in Figure 16. Similar to the other investigated points, liquefaction also happens on shallow depth dominated by SP, as shown in Figure 16a. The critical liquefaction also happens on silty sand layers interpreted by Figure $16 \mathrm{~b}$ to $16 \mathrm{~d}$. In SC Layer, at depth of 25.5 (Figure $16 \mathrm{e})$, the excess pore water pressure is not large enough to pass the initial effective stress.
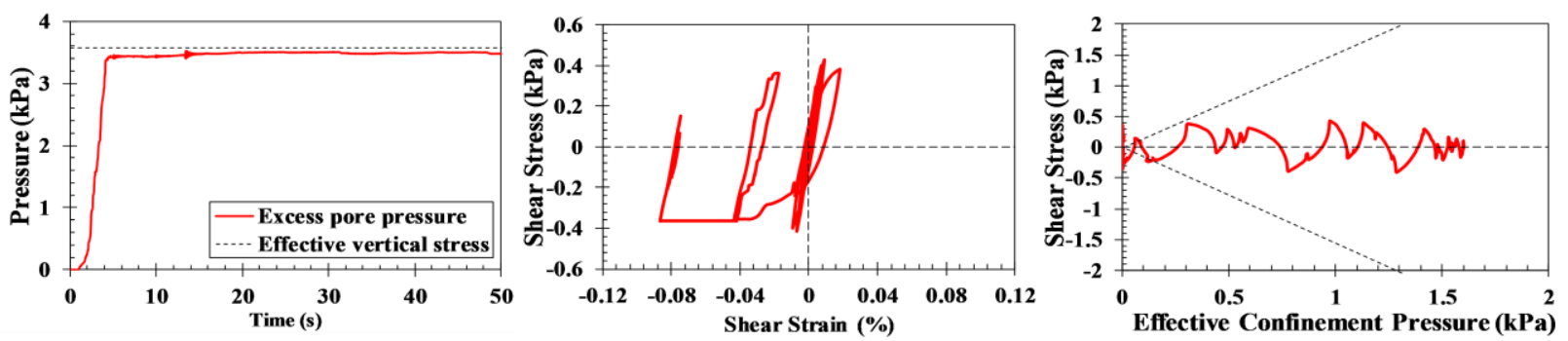

(a) Layer 1 (at depth of $0.5 \mathrm{~m}$ )
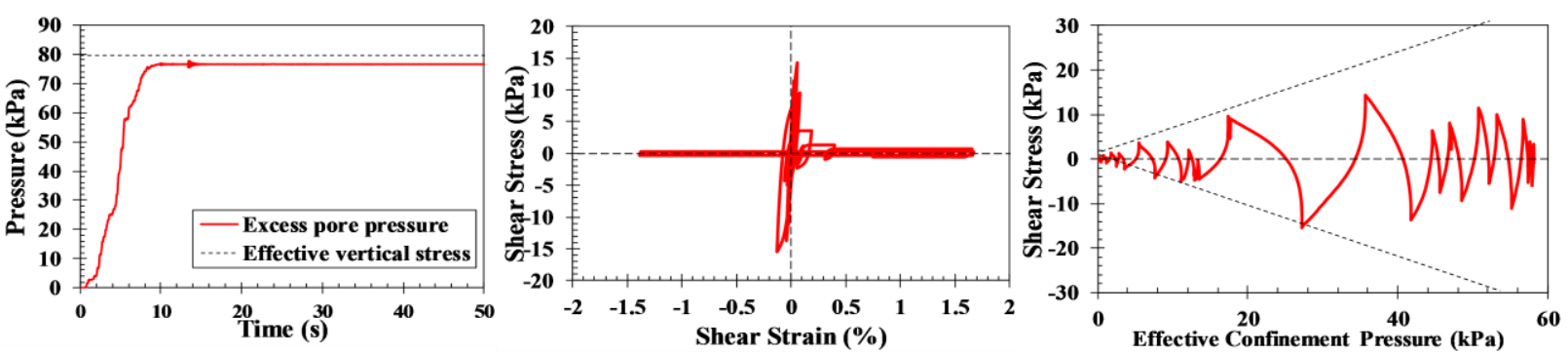

(b) Layer 2 (at depth of $9 \mathrm{~m}$ )
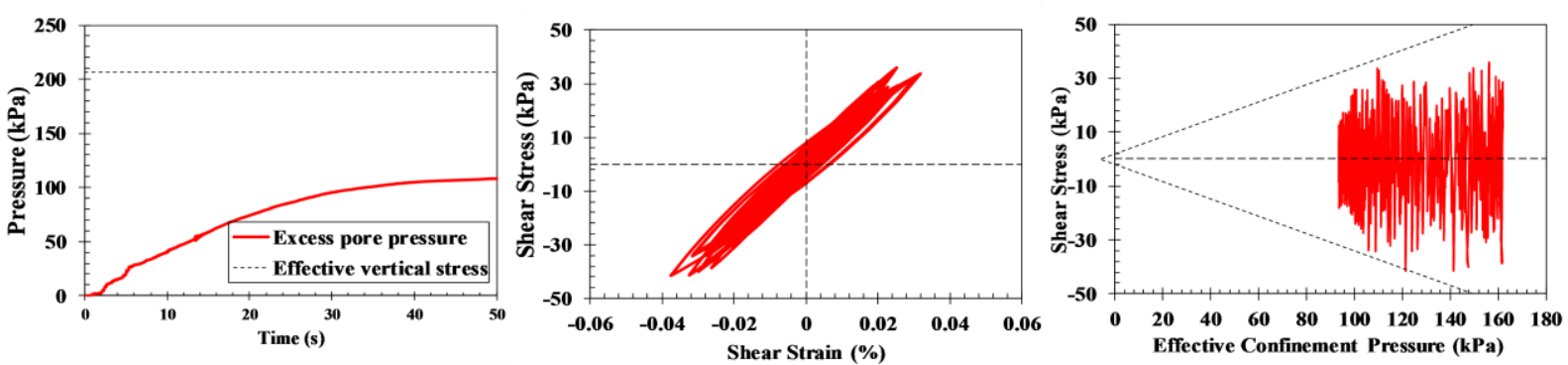

(c) Layer 3 (at depth of $22 \mathrm{~m}$ )

Figure 12. Soil Behaviour of BH-1 Due to Synthetic of the 2007 Earthquake
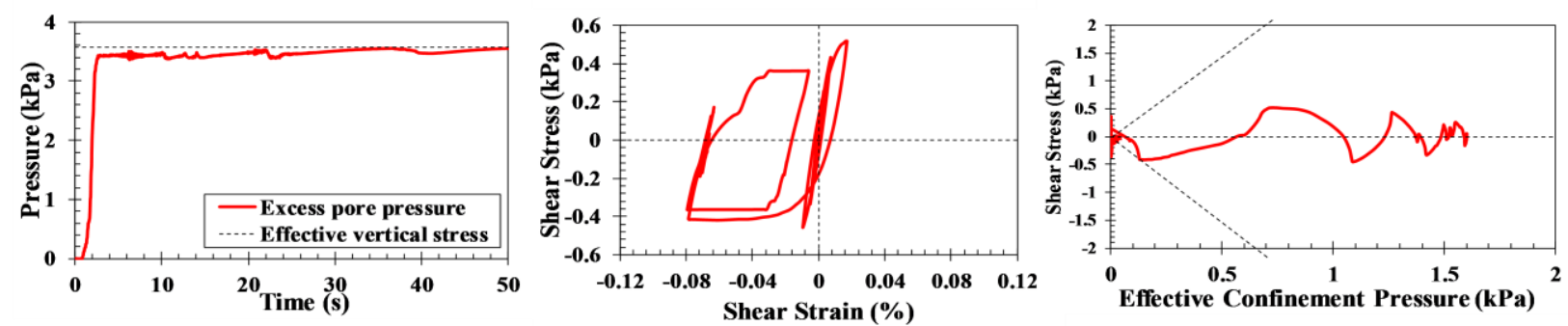

(a) Layer 1 (at depth of $0.5 \mathrm{~m}$ )
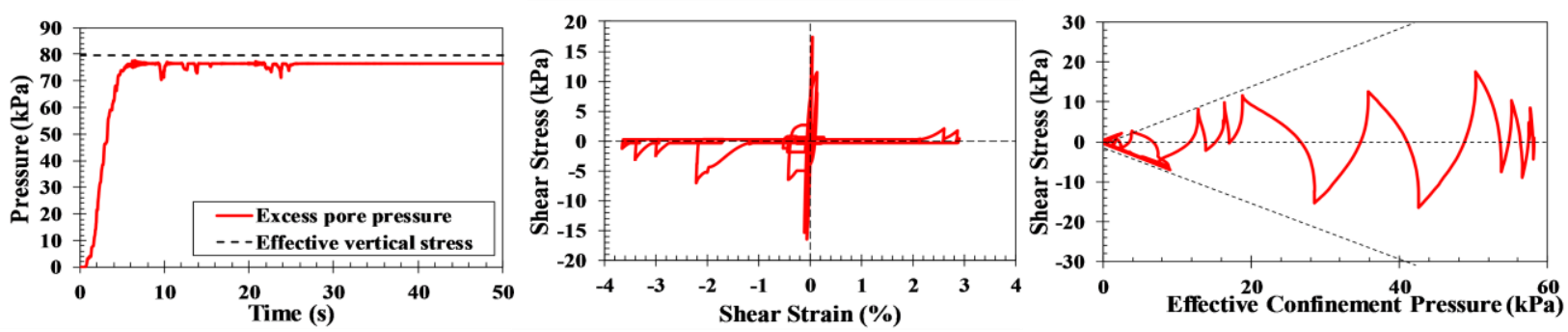

(b) Layer 2 (at depth of $9 \mathrm{~m}$ ) 

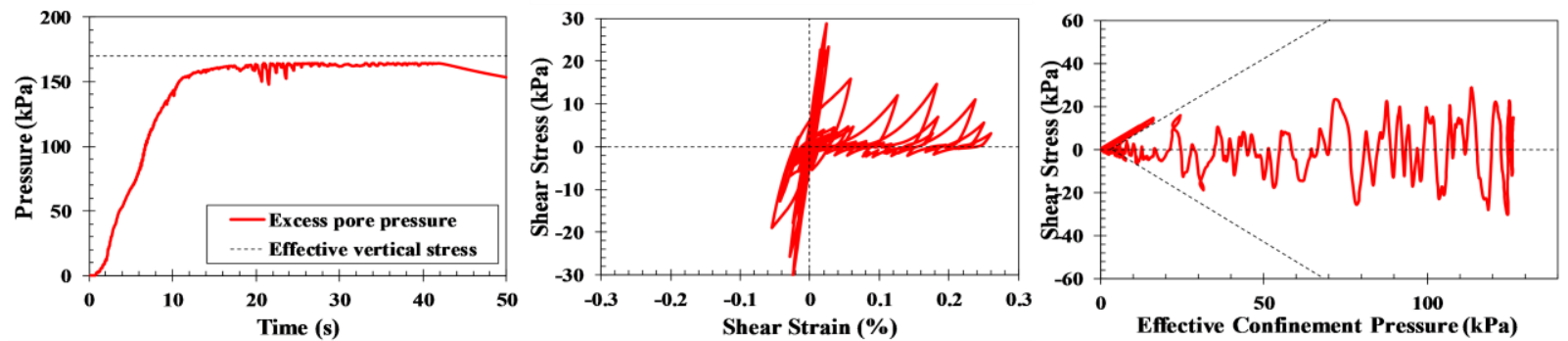

(c) Layer 3 (at depth of $18.5 \mathrm{~m}$ )
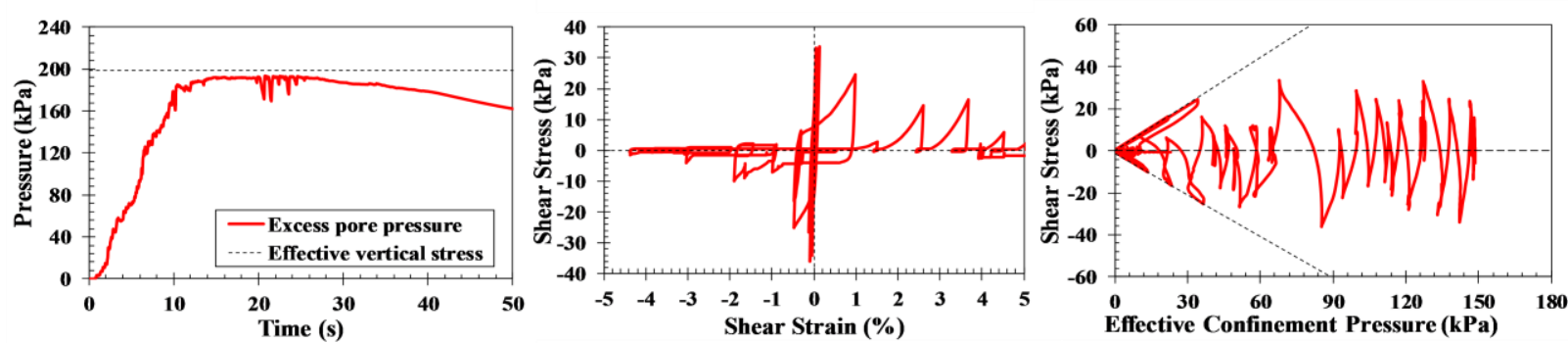

(d) Layer 4 (at depth of $21.5 \mathrm{~m}$ )
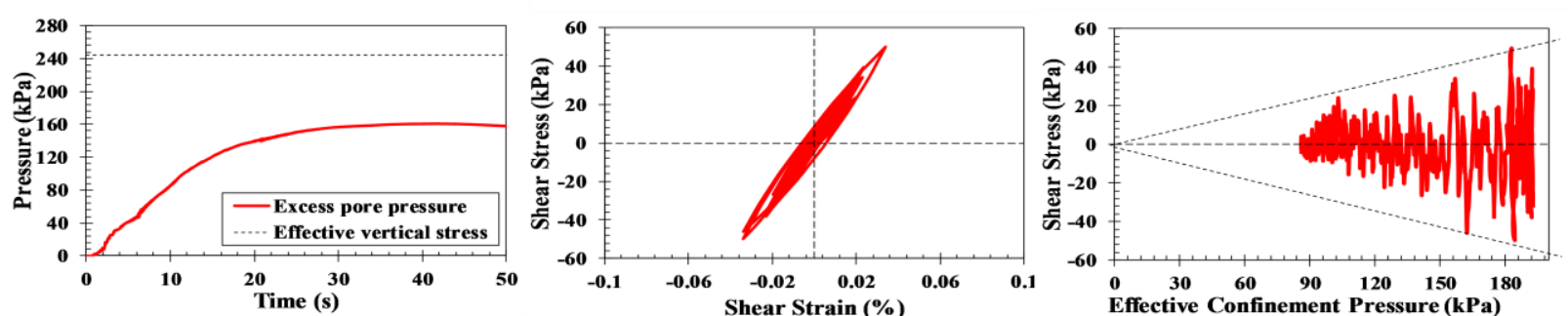

(e) Layer 5 (at depth of $26.5 \mathrm{~m}$

Figure 13. Soil Behaviour of BH-2 due to Synthetic Motion of the 2000 Earthquake
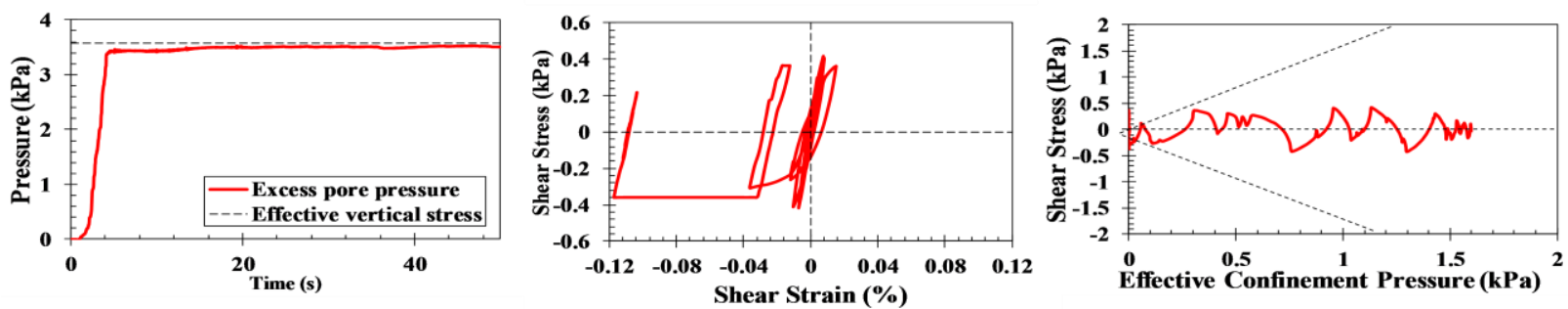

(a) Layer 1 (at depth of $0.5 \mathrm{~m}$ )
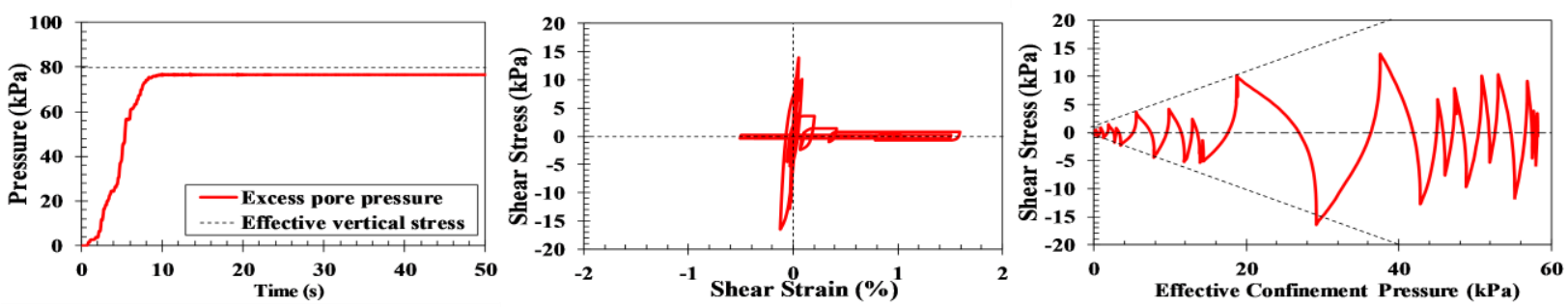

(b) Layer 2 (at depth of $9 \mathrm{~m}$ )
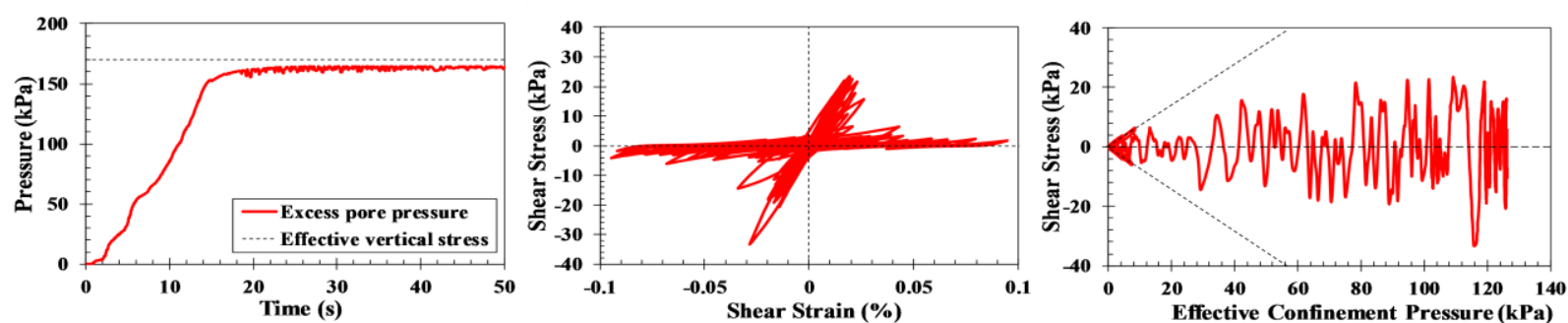

(c) Layer 3 (at depth of $18.5 \mathrm{~m}$ ) 

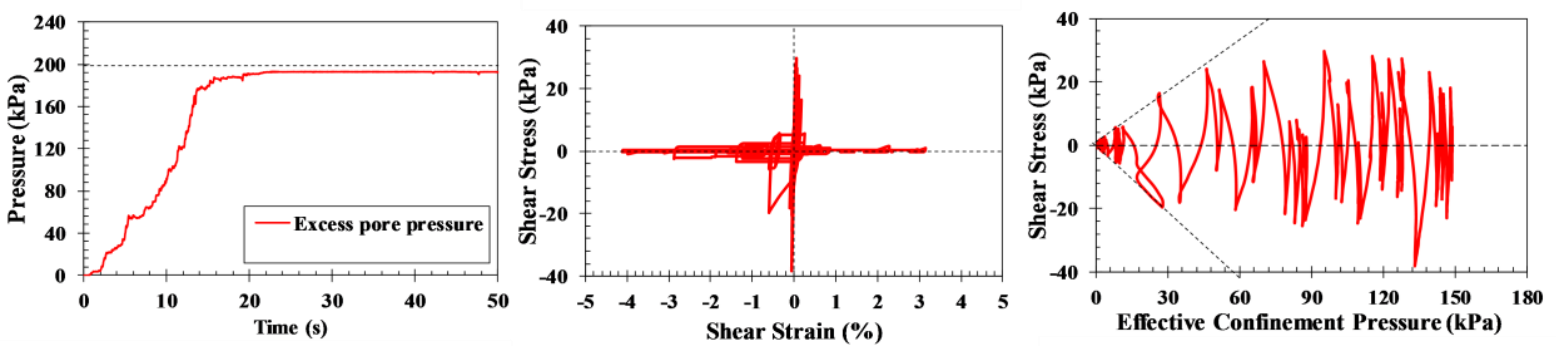

(d) Layer 4 (at depth of $21.5 \mathrm{~m}$ )
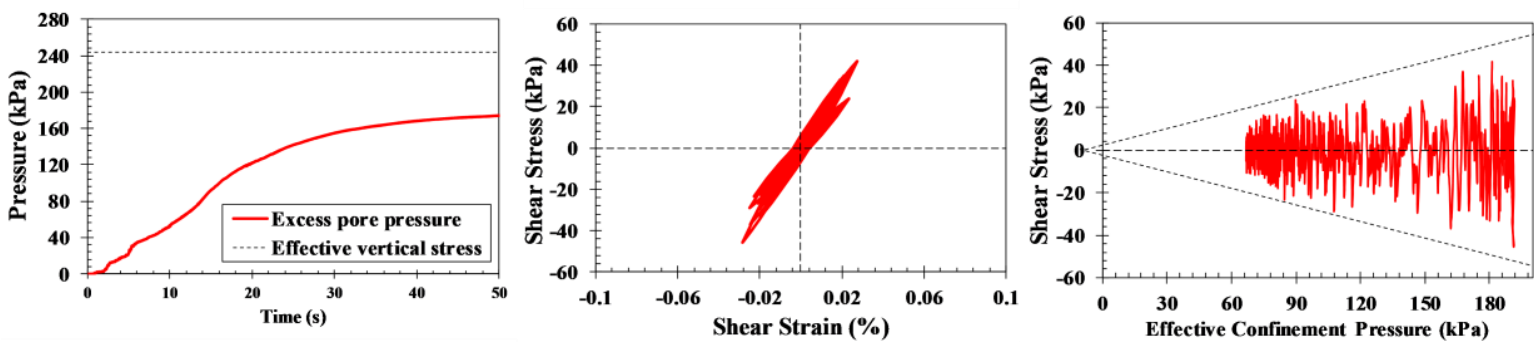

(e) Layer 5 (at depth of $26.5 \mathrm{~m}$ )

Figure 14. Soil Behaviour of BH-2 Due to Synthetic Motion of the 2007 Earthquake
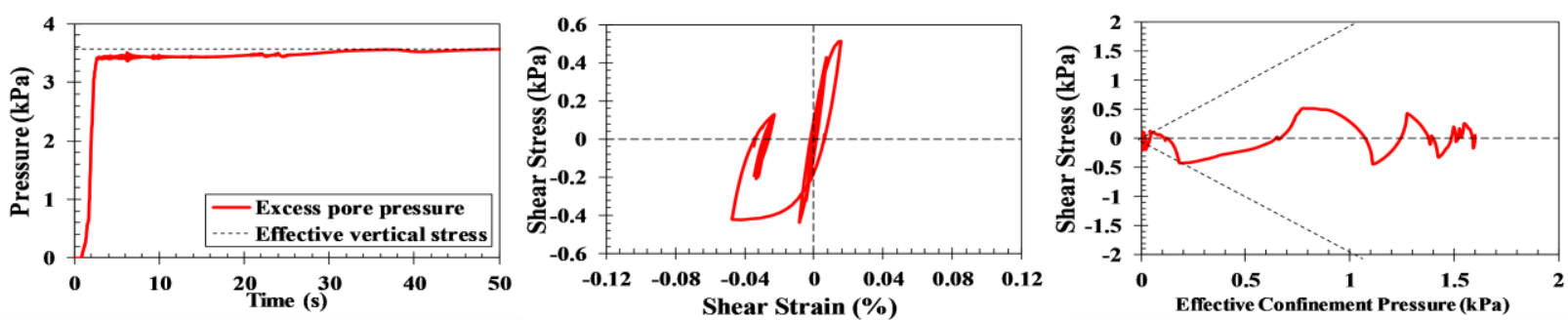

(a) Layer 1 (at depth of $0.5 \mathrm{~m}$ )
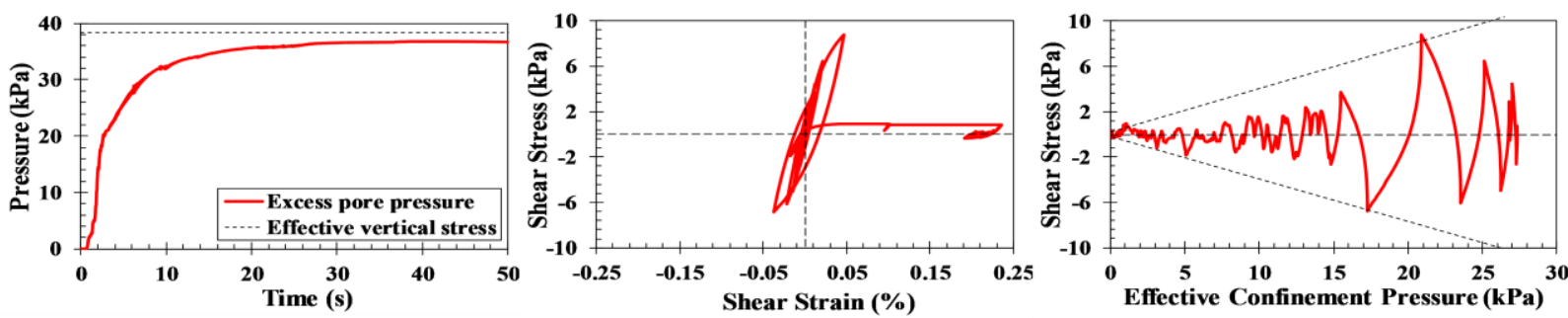

(b) Layer 2 (at depth of $4.5 \mathrm{~m}$ )
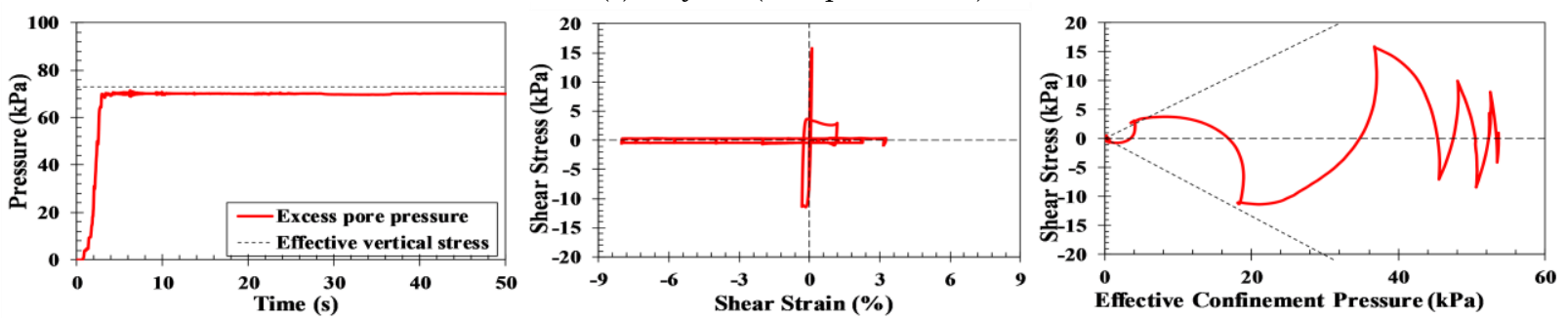

(c) Layer 3 (at depth of $8.5 \mathrm{~m}$ )
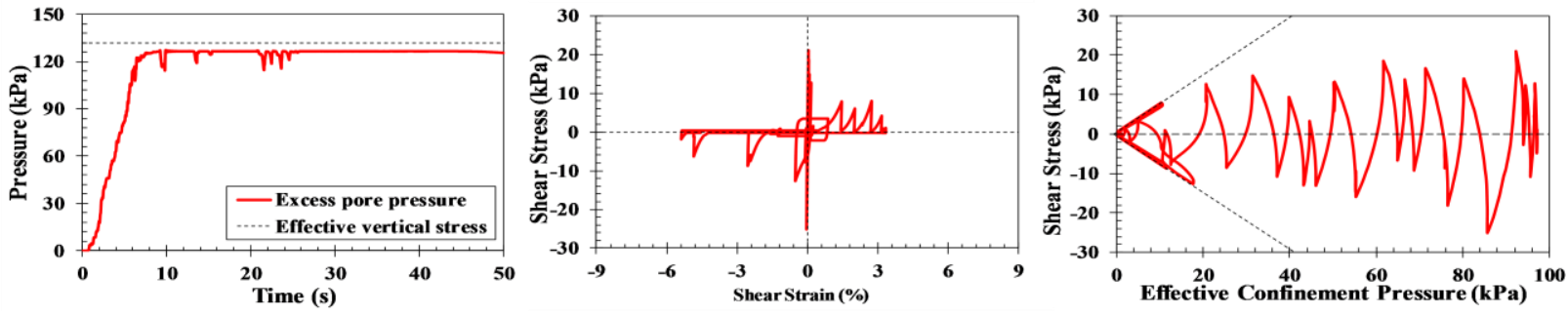

(d) Layer 4 (at depth of $15 \mathrm{~m}$ ) 

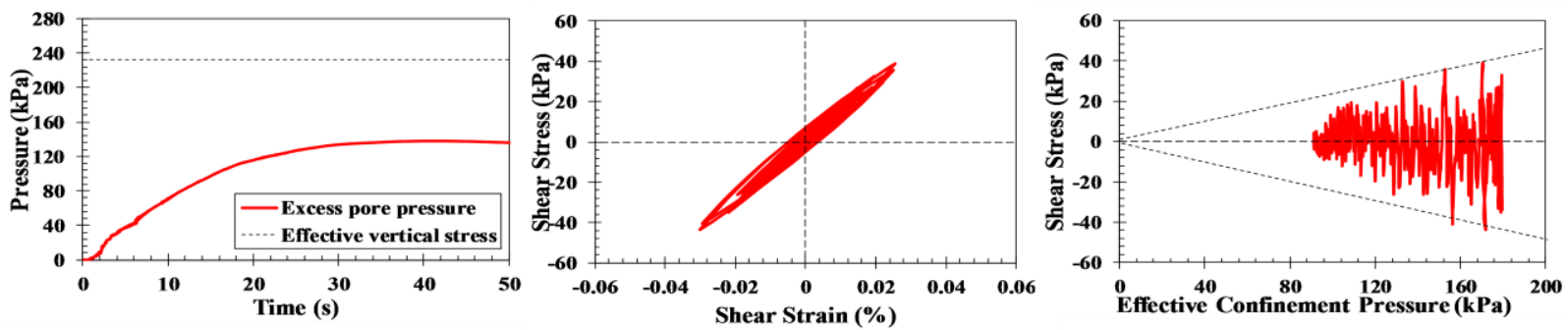

(e) Layer 5 (at depth of $25.5 \mathrm{~m}$ )

Figure 15. Soil Behaviour of BH-3 due to Synthetic Motion of the 2000 Earthquake
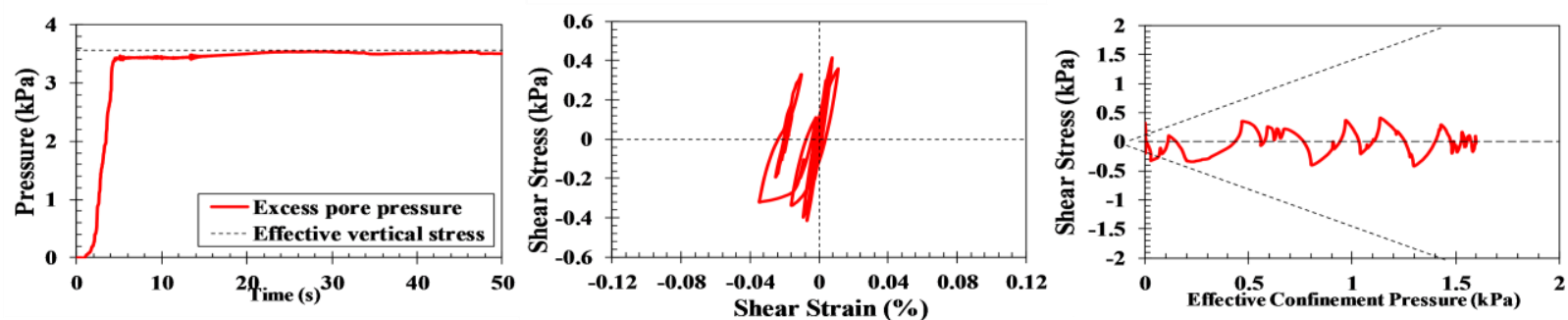

(a) Layer 1 (at depth of $0.5 \mathrm{~m}$ )
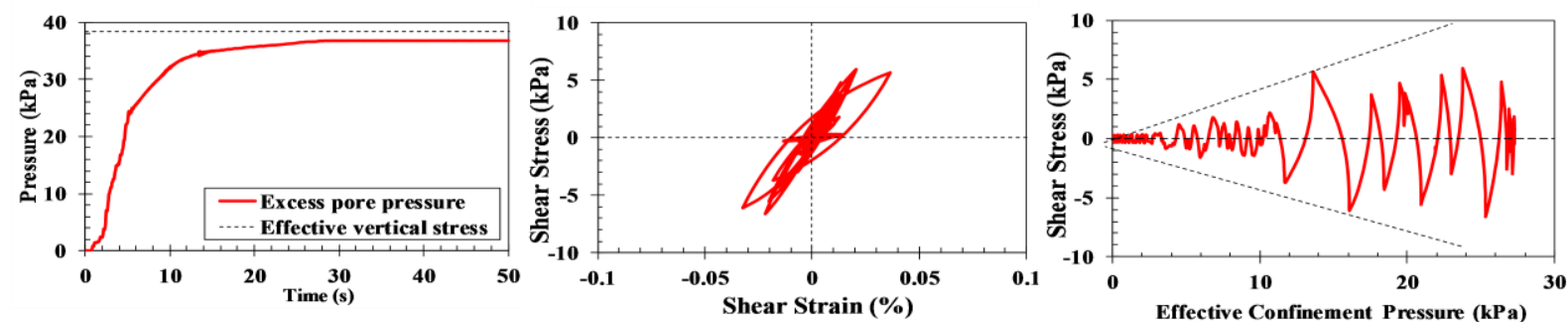

(b) Layer 2 (at depth of $4.5 \mathrm{~m}$ )
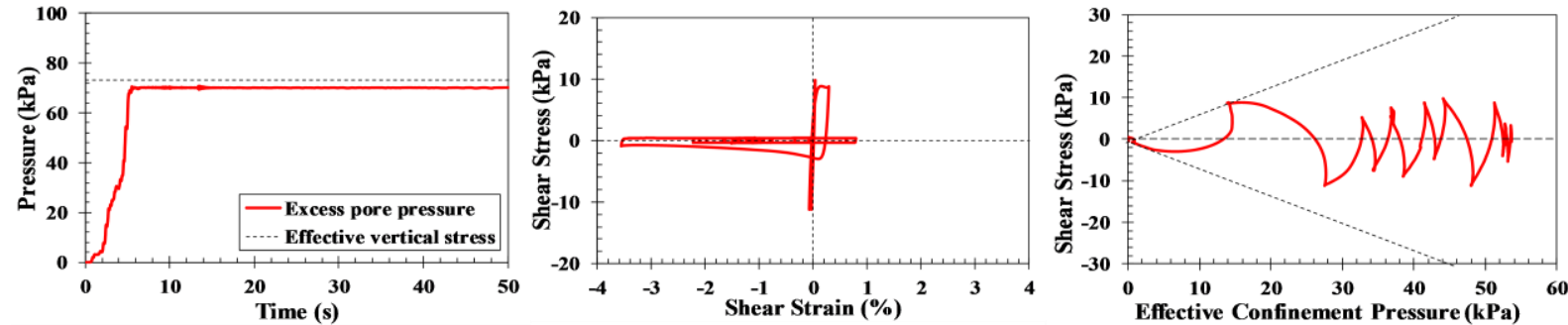

(c) Layer 3 (at depth of $8.5 \mathrm{~m}$ )
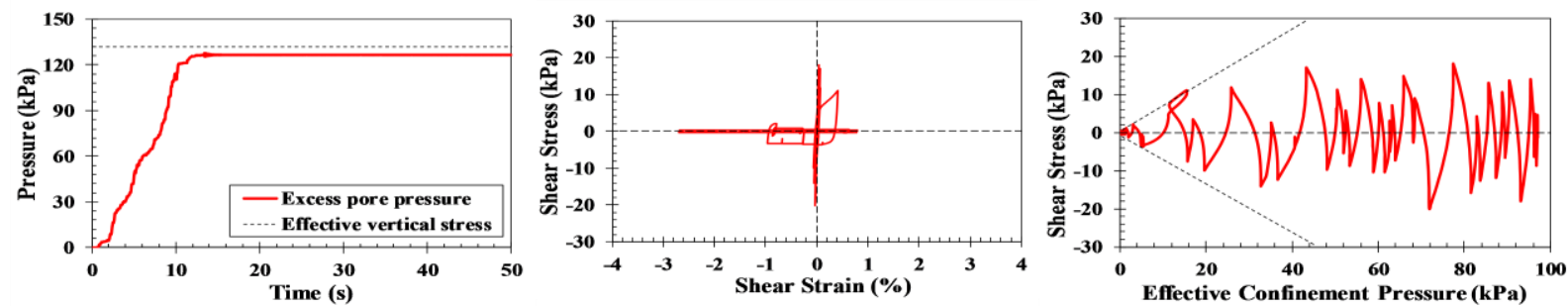

(d) Layer 4 (at depth of $15 \mathrm{~m}$ )
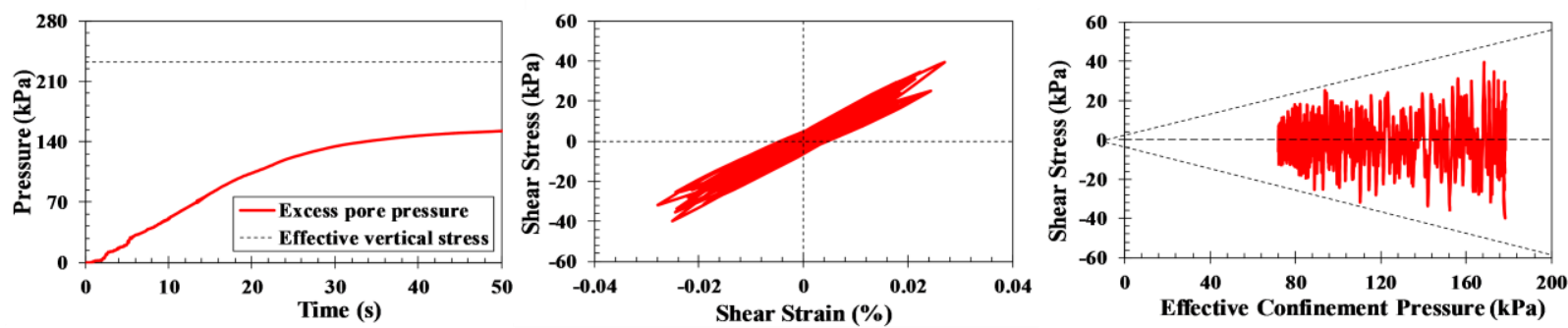

(e) Layer 5 (at depth of $25.5 \mathrm{~m}$

Figure 16. Soil Behaviour of BH-3 due to Synthetic Motion of the 2007 Earthquake 


\section{Concluding Remarks}

During both the 2000 and 2007 earthquakes, liquefaction occurred on each investigated location, especially at shallow depth (0 to $1.5 \mathrm{~m})$ dominated by loose sand with low $\left(\mathrm{N}_{1}\right)_{60}$. The critical depth was also generally observed in silty sand layer, i.e. from 1.5 to $20 \mathrm{~m}$ deep. The layers, which had $r_{u}$ about 0.9 to 1 , are possible to undergo the liquefaction if the stronger earthquake happens. At depth of $20 \mathrm{~m}$ to 30 $\mathrm{m}$, the excess pore water pressure was not able to trigger liquefaction. The earthquake energy produced by the 2007 earthquake and 2000 earthquake influenced the propagating wave in generating the excess pore water pressure. Based on the results, the impacted depth caused by both 2000 and 2007 earthquakes is relatively deep. This result was also confirmed by the horizontal displacement showing that both earthquakes result in a large horizontal displacement at the ground surface. In term of the vulnerability of sites, Pantai Panjang site was the most vulnerable area to undergo liquefaction during both events. This site was also identified as the most critical location, because $r_{u}$ of 0.9 to 1 , was dominant in this site.

\section{Acknowledgement}

The author is grateful to Soil Mechanics Laboratory of Civil Engineering Department for supporting site investigation data used in this study.

\section{References}

1. Muktadir, R., Evaluasi Potensi Likuifaksi dengan Metode Deterministik berdasarkan Data Cone Penetration Test (Studi Kasus Kelurahan Lempuing, Kota Bengkulu), Undergraduate Thesis, Department of Civil Engineering, University of Bengkulu, Indonesia, 2013.

2. SNI 03-1726-2012, Tata Cara Perencanaan Ketahanan Gempa Untuk Struktur Bangunan Gedung dan Non Gedung, Badan Standarisasi Nasional Indonesia, 2010.

3. Misliniyati, R., Mawardi, Besperi, Razali, M.R., and Muktadir R., Pemetaan Potensi Likuifaksi Wilayah Pesisir berdasarkan Data Cone Penetration Test di Kelurahan Lempuing, Kota Bengkulu, Inersia, 5(2), 2013, pp. 1-8.

4. Monalisa, A., Analisis Potensi Likuifaksi dengan Metode Probabilitas Sederhana berdasarkan Data Cone Penetration Test di Kelurahan Lempuing, Kota Bengkulu, Undergraduate Thesis, Department of Civil Engineering, University of Bengkulu, Indonesia, 2014.

5. Mase, L.Z. and Sari, A.N., A Preliminary Evaluation of Liquefaction Potential of Sandy Soil in Lempuing Sub-District (A Coastal Area in Bengkulu City), Inersia, 7(2), 2015, pp.21-25
6. Mase, L. Z. and Somantri, A. K., Analisis Potensi Likuifaksi di Kelurahan Lempuing Kota Bengkulu menggunakan Percepatan Maksium Kritis, Potensi, 25(1), 2016, pp.1-11.

7. Mase, L. Z. and Somantri, A. K., Liquefaction Study using Shear Wave Velocity (Vs) Data in Coastal Area of Bengkulu City, Proceeding Seminar Nasional Geoteknik 2016.

8. Mase, L.Z., Studi Kehandalan Metode Analisis Likuifaksi Menggunakan SPT Akibat Gempa 8,6 $\mathrm{M}_{\mathrm{w}}, 12$ September 2007 di Area Pesisir Kota Bengkulu, Jurnal Teknik Sipil, 25(1), 2018, pp. 53-60. doi: 10.5614/jts.2018.25.1.7.

9. Mase, L.Z., Liquefaction Potential Analysis along Coastal Area of Bengkulu Province due to the $2007 \mathrm{M}_{\mathrm{w}}$ 8.6 Bengkulu Earthquake, Journal of Engineering and Technological Sciences, 49(6), 2018, pp. 721-736. doi: 10.5614/j.eng.technol.sci. 2017.49.6.2.

10. Hakam, A., Soil Liquefaction in Padang due to Padang Earthquake 30 September 2009, Civil Engineering Dimension, 14(2), 2012, pp. 64-68, retrieved from http://ced.petra.ac.id/index.php/ civ/article/view/18450/18266.

11. Yogatama, B.A. and Fathani, T.F., Liquefaction Potential Analysis on Bantul Regency and Yogyakarta City Area, Proceeding of PIT HATTI XVII, Jakarta, Indonesia, November 13-14, 2013, pp. 205-210.

12. Tohari, A., Soebowo, E., Wardana, D.D., Irianto, B., and Widodo., Potensi Bahaya Likuifaksi di Daerah Banda Aceh dan Sekitarnya, Technical Report of Mitigasi Bahaya Gerakan Tanah di Daerah Tropis dan Tektonik Aktif, Puslit Geoteknologi LIPI, 2007.

13. Tohari, A., Sugianti, K., Syahbana, A.J., and Soebowo, E., Kerentanan Likuifaksi Wilayah Kota Banda Aceh Berdasarkan Metode Uji Penetrasi Konus, Riset Geologi dan Pertambangan, 25(2), 2015, pp.99-110, doi:10.14203/ risetgeotam2015.v25.204.

14. Tobita, T., Iai, S., Chairullahanta, B., and Asper, W., Reconnaissance Report of the 2004 Great Sumatra-Andaman, Indonesia Earthquake Damage to Geotechnical Works in Banda Aceh and Meulaboh, Natural Disaster Science, 28(1), 2006, pp. 35-41.

15. Google Earth, Bengkulu Province Region, 2016, https://www.google.co.id/

16. National Earthquake Hazard Reduction Program (NEHRP), Recommended Provisions for Seismic Regulation for New Buildings and Other Structures 1997 Edition, FEMA 302, USA, 1998

17. Pender, M.J., Orense, R.P., Wotherspoon, L.M., and Storie, L.B., Effect of Permeability on Cyclic Generation and Dissipation of Pore Pressure in Saturated Gravel Layers, Geotechnique, 66(4), 2016, pp. 313-322, doi:10.1680/jgeot.SIP.15.P.024. 
18. Ishihara, K., Tatsuoka, F., and Yasuda, S., Undrained Deformation and Liquefaction of Sand under Cyclic Stresses, Soils and Foundation, 15(1), 1975, pp. 29-44.

19. Parra, E., Numerical Modeling of Liquefaction and Lateral Ground Deformation Including Cyclic mobility and Dilation Response in Soil System, PhD Thesis, Rensselaer Polytechnic Institute, New York, USA, 1996.

20. Yang, Z., Numerical Modeling of Earthquake Site Response Including Dilation and Liquefaction, PhD Dissertation, Columbia University, New York, USA, 2000.

21. Prevost, J.H., A Simple Plasticity Theory for Frictional Cohesionless Soils, Soil Dynamics and Earthquake Engineering, 4(1), 1985, pp. 9-17.

22. Elgamal, A., Yang, Z., and Lu, J., Cyclic1D: $A$ Computer Program for Seismic Ground Response, Report No. SSRP-06/05, Department of Structural Engineering, University of California, San Diego, USA, 2006

23. Mase, L.Z., Tobita, T., and Likitlersuang, S., Liquefaction Potential in Chiang Rai Province, Northern Thailand due to the 6.8 $\mathrm{M}_{\mathrm{w}}$ Earthquake on March 24, 2011, Proceeding of the 36th Conference on Earthquake Engineering, JSCE, Kanazawa, Japan, 17-18 October, 2016.
24. Refrizon, Hadi, A.I., Lestari, K., and Octari, T., Analisis Percepatan Getaran Tanah Maksimum dan Tingkat Kerentanan Seismik Daerah Ratu Agung Kota Bengkulu, Proceeding of Semirata FMIPA UNILA, Lampung, 10-12 May, 2013.

25. Mase, L.Z., Likitlersuang, S., and Tobita, T., Non-Linear Site Response Analysis of Soil Sites In Northern Thailand during the $\mathrm{M}_{\mathrm{w}}$ 6.8 Tarlay Earthquake, Engineering Journal, 22(3), 2018, pp. 291-303. doi: 10.4186/ej.2018.22.3.291.

26. Seismosoft, SeismoArtif Program, 2016 Seismosoft, http://www.seismosoft.com.

27. SNI 03-1726-2012, Tata Cara Perencanaan Ketahanan Gempa untuk Struktur Bangunan Gedung dan Non Gedung, Badan Standarisasi Nasional, Jakarta, Indonesia, 2012.

28. Arya, A.S., Constultant Report on Field Survey of Natural Disaster Based on Visits to Indonesia (Bengkulu, Bandung), NEPAL (Kathmandu), India (Chamoli), UN/DESA PROJECT-INT/98/ X70, UNCRD, 2002.

29. Earthquake Engineering Research Institute (EERI), EERI Special Earthquake Report: Learning from Earthquakes Observation on the Southern Sumatra Earthquakes of September 12-13, 2007, Earthquake Engineering Research Institute, 2007. 